\title{
Protein contents and binding modes of immunoglobulin-amylase complexes
}

\author{
H OHTANI, K SAKAGUCHI, M SAITO \\ From the Department of Clinical Pathology, Kitasato University School of Medicine, Kitasato 1-15-1, \\ Sagamihara City, Kanagawa Ken, 228, Japan
}

SUMMARY The protein contents and binding modes of immunoglobulin-amylase complexes were investigated. Amylase staining after immunoelectrophoresis permitted identification of $\operatorname{IgA}-\lambda$ type in three cases, IgA- $\kappa$ type in two cases and IgG- $\kappa$ type in one case. The precipitin line of Fab fragment of IgA in four patient's sera after papain digestion was found to have amylase activity. Sucrose density gradient ultracentrifugation studies showed that these complexes were divided into three groups:

Group I complexes were dissociated in acid pH, and at $\mathrm{pH} 7.0$ the immunoglobulins, which were isolated at the acid $\mathrm{pH}$, became rebound to serum amylase;

Group II complexes were dissociated by acidification, but did not reform at $\mathrm{pH} 7 \cdot 0$;

Group III complexes were unaffected by acidification. We suggest that the immunoglobulin-amylase complexes belonging to groups I and II result from an antigen-antibody reaction. Precipitin curves resulting from the addition of increasing quantities of the patient's serum containing $9 \mathrm{~S}$ or $11 \mathrm{~S}$ immunoglobulin-amylase complexes to specific antisera revealed that these complexes contained not only monoclonal IgA, but also alpha-1-antitrypsin $\left(a_{1} \mathrm{AT}\right)$ and albumin. These IgA complexes could have bound non-specifically to $a_{1} \mathrm{AT}$ and albumin, forming the larger macroamylase complexes.

An abnormally large serum amylase, macroamylase, was first described in 1964 by Wilding et al, 1 and the term macroamylasemia was introduced in 1967 by Berk et al. ${ }^{2}$ The macroamylasemia has been shown to be due to the following: (i) polymerisation of normal serum amylase; (ii) the formation of an enzyme-substrate complex from amylase and the polysaccharide ; $^{4}$ and (iii) an immunoglobulinamylase complex..$^{5}$ Although approximately 40 cases with macroamylasemia have been reported in Japan, almost all have been shown to be composed of Ig-amylase complexes.?

Heterogeneity of Ig-amylase complexes has been reported concerning molecular size ${ }^{8} 9$ and dissociation by treatment with acid $\mathrm{pH} .{ }^{10}$ Whether or not the binding modes of these Ig-amylase complexes are attributable to an antigen-antibody reaction is still unclear.

The present paper deals with the protein contents and binding characteristics in the Ig-amylase complexes.

\section{Material and methods}

Macroamylase sera from six patients were examined (Table 1). Amylase activity in serum and urine was assayed by the blue dye-starch method (PharmaciaDaiichi Chem, Japan). Serum Ig concentrations were determined by single radial immunodiffusion using Immunoplates (Hyland, USA). The binding of serum-amylase to Ig was studied by determining the percentage of amylase remaining in the supernatant after immunoprecipitation of the serum IgG, IgA and IgM with commercial goat-specific antisera (Behringwerke, Germany). The binding of the Igamylase complexes to albumin and $\alpha_{1} \mathrm{AT}$ was also studied by determining the percentage of amylase remaining in the supernatant after immunoprecipitation of the serum albumin and $a_{1}$ AT with commercial goat antialbumin and horse anti- $a_{1}$ AT antisera (Behringwerke). Increasing volumes of the patient's serum were added to the antiserum and incubated at $37^{\circ} \mathrm{C}$ for $1 \mathrm{~h}$ and then at $4^{\circ} \mathrm{C}$ overnight. The protein content of the precipitate was determined by OD 280. After the samples had been centrifuged, 
Table 1 Pathological features, values of serum immunoglobulins; amylase activities of serum and urine, and serum autoantibodies in macroamylasemia

\begin{tabular}{|c|c|c|c|c|c|c|c|c|c|}
\hline \multirow[t]{2}{*}{ Case } & \multirow{2}{*}{$\begin{array}{l}\text { Age } \\
(y r)\end{array}$} & \multirow{2}{*}{$\operatorname{Sex}$} & \multirow[t]{2}{*}{ Diagnosis } & \multicolumn{3}{|c|}{$\operatorname{Serum}(g / l)$} & \multicolumn{2}{|c|}{$\begin{array}{l}\text { Amylase (Phadebas } \\
\text { units) }\end{array}$} & \multirow[t]{2}{*}{ Autoantibody } \\
\hline & & & & $I g G$ & $\operatorname{IgA}$ & $I g M$ & Serum & Urine & \\
\hline $1 *$ & 62 & $\mathbf{M}$ & $\begin{array}{l}\text { Chronic pancreatitis } \\
\text { Liver cirrhosis } \\
\text { Cholelithiasis } \\
\text { Alcoholic }\end{array}$ & $22 \cdot 5$ & $12 \cdot 0$ & 1.0 & 960 & 32 & $(-)$ \\
\hline $\begin{array}{l}2 \\
3 *\end{array}$ & $\begin{array}{l}65 \\
45\end{array}$ & $\begin{array}{l}\mathbf{M} \\
\mathbf{M}\end{array}$ & $\begin{array}{l}\text { Chronic pancreatitis } \\
\text { Chronic pancreatitis } \\
\text { Liver cirrhosis } \\
\text { Diabetes mellitus } \\
\text { Alcoholic }\end{array}$ & $\begin{array}{l}14 \cdot 0 \\
22 \cdot 0\end{array}$ & $\begin{array}{l}2 \cdot 7 \\
1 \cdot 0\end{array}$ & $\begin{array}{l}0 \cdot 86 \\
2 \cdot 1\end{array}$ & $\begin{array}{l}500 \\
502\end{array}$ & $\begin{array}{l}32 \\
32\end{array}$ & $\begin{array}{l}(-) \\
\text { RA test }(+) \\
\text { Anti-DNA } 160 \times(+)\end{array}$ \\
\hline 4 & 78 & $\mathbf{M}$ & $\begin{array}{l}\text { Cerebral thrombosis } \\
\text { Gastric ulcer } \\
\text { Old-healed myocardial infarction }\end{array}$ & $15 \cdot 0$ & 7.8 & $1 \cdot 1$ & 3500 & & $(-)$ \\
\hline 5 & 77 & $\mathbf{M}$ & $\begin{array}{l}\text { Abdominal aneurysm } \\
\text { Ischaemic heart disease } \\
\text { Stone of prostate }\end{array}$ & $25 \cdot 0$ & $7 \cdot 0$ & $0 \cdot 88$ & 1080 & 64 & \\
\hline 6 & 76 & $\mathbf{M}$ & $\begin{array}{l}\text { Pulmonary carcinoma } \\
\text { Pulmonary tuberculosis }\end{array}$ & $17 \cdot 0$ & $4 \cdot 4$ & $1 \cdot 0$ & 1020 & & Anti-DNA $80 \times(+)$ \\
\hline
\end{tabular}

*Necropsy carried out.

amylase was measured in the supernatant fluid.

Immunoelectrophoresis (IEP) using a stabilising medium of Cello-gel (Chemetron, Italy) was carried out, developed with anti- $\gamma$, anti- $\alpha$, anti- $\kappa$ and anti- $\lambda$ antisera. The sera after papain digestion according to the method of Potter ${ }^{11}$ were also used. Staining of the precipitin line which appeared after IEP was performed with an agar plate containing blue dyestarch. ${ }^{7}$ To stain the precipitin line on the stabilising medium, it was laid on the agar plate of the blue dye-starch for approximately one hour at $37^{\circ} \mathrm{C}$. The agar plate was prepared as follows: $5 \mathrm{ml}$ of $2 \%$ agar solution at $60^{\circ} \mathrm{C}$ was mixed with $5 \mathrm{ml}$ of distilled water containing five tablets of the blue dye-starch (Pharmacia-Daiichi Chem, Japan), poured in the Petri dish and solidified.

Sucrose density gradient ultracentrifugation (SDGU) was performed, ${ }^{9}$ using a Hitachi RPS 50. Serum $(0.2 \mathrm{ml})$ was applied to $4.6 \mathrm{ml}$ of 10 to $40 \%$ of linear gradient sucrose in $0.01 M$ phosphatebuffered saline (PBS) solution (pH 7.0) or $0.05 \mathrm{M}$ glycine-hydrochloride buffer (pH 3.4), which was spun at $45000 \mathrm{rpm}$ at $4^{\circ} \mathrm{C}$ for $24 \mathrm{~h}$. Fractions $(0.2 \mathrm{ml})$ were serially collected. After the protein content was determined by OD 280 , amylase activity was measured. The protein components in the fractions were identified by Ouchterlony's technique. The fractions containing IgA or IgG dissociated after SDGU at pH 3.4 were collected, adjusted to pH 7.0 with $0.1 \mathrm{~N}$ sodium hydroxide, and added to $0.1 \mathrm{ml}$ of pancreatitis serum. After that SDGU was also performed at $\mathrm{pH} \mathbf{7 \cdot 0}$. In a few studies, the gradients were modified by the incorporation of
0.1 M 2-mercaptoethanol into the sucrose gradients and the PBS solution ( $\mathrm{pH} \mathrm{7.0).}$

\section{Results}

The clinical features and laboratory data of $\mathrm{Ig}$ and amylase activities are shown in Table 1 . Of 6 patients three were associated with chronic pancreatitis. The other three patients without pancreatitis showed polyclonal hyperimmunoglobulinaemia. Autoantibodies including anti-DNA and RA factor were found in two patients.

In order to determine classes and types of $\mathrm{Ig}$ in the Ig-amylase complexes, amylase staining after IEP was performed (Fig. 1). It permitted identification of IgA- $\lambda$ type in three cases, IgA- $\kappa$ type in two cases and IgG- $\kappa$ type in one case (Table 2). The precipitin lines of Fab fragments in four sera after

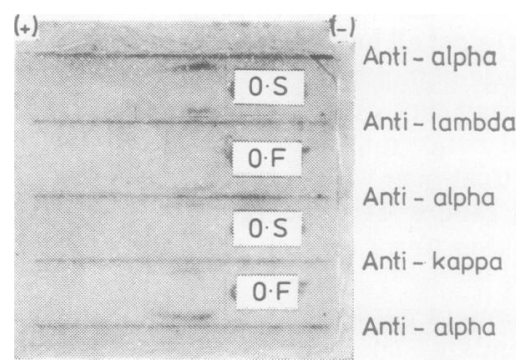

Fig. 1 Amylase staining after immunoelectrophoresis. OS (case 5) was identified as IgA-lambda ( $\lambda)$ type and SF (case 4) as IgA-kappa (к) type. 
Table 2 Protein contents and immunochemical features of immunoglobulin-amylase complexes

\begin{tabular}{|c|c|c|c|c|c|c|}
\hline \multirow[t]{2}{*}{ Case } & \multicolumn{3}{|c|}{ Protein contents } & \multirow{2}{*}{$\begin{array}{l}\text { Sedimentation } \\
\text { coefficient }\end{array}$} & \multirow{2}{*}{$\begin{array}{l}\text { Dissociation of } \\
\text { Ig-amylase complex at } \\
\text { pH } 3.4\end{array}$} & \multirow{2}{*}{$\begin{array}{l}\text { Rebinding of Ig to } \\
\text { amylase at } \mathrm{pH} 7 \cdot 0\end{array}$} \\
\hline & $I g$ & $a_{1} A T$ & Albumin & & & \\
\hline 1 & $\lg \mathbf{A}-\lambda$ & + & + & $11 \mathrm{~S}$ & $\ldots$ & - \\
\hline 2 & $\operatorname{IgA}-\lambda$ & - & - & $7 S$ & + & + \\
\hline 3 & IgA- $\kappa$ & - & - & $7 \mathrm{~S}$ & + & + \\
\hline 4 & $\operatorname{Ig} \mathbf{A}-\kappa$ & - & - & $7 \mathrm{~S}$ & $\div$ & + \\
\hline 5 & $\operatorname{IgA}-\lambda$ & + & + & $9 \mathrm{~S}$ & - & \\
\hline 6 & IgG- $\kappa$ & - & - & $7 S$ & + & + \\
\hline
\end{tabular}

papain digestion were found to have amylase activity.

SDGU studies at $\mathrm{pH} \mathbf{7 . 0}$ showed normal size (about $4.5 \mathrm{~S}$ ) of amylase in sera of healthy controls and patients with acute pancreatitis, while four of six cases with macroamylase complexes were $7 \mathrm{~S}$, and the other two cases $9 \mathrm{~S}$ and $11 \mathrm{~S}$, respectively (Fig. 2 and Table 2). At pH 3.4 the sedimentation coefficients of macroamylase complexes were reduced to that of normal amylase in five cases. After SDGU at $\mathrm{pH} 3 \cdot 4$, the $\mathrm{pH}$ of dissociated and fractionated Ig was adjusted to $7 \cdot 0$ with $0.1 \mathrm{~N}$ sodium hydroxide and $0.1 \mathrm{ml}$ of pancreatitis serum was added to the solu- tion. These fractionated serum Ig bound the normalsized amylase present in the pancreatitis serum and converted the amylase to a large, macroamylase complex as demonstrated by SDGU at pH 7.0 (Fig. 2a). The Ig obtained after SDGU at $\mathrm{pH} 3.4$ did not bind amylase in one (case 1) of five cases (Fig. 2b). On the other hand, the Ig-amylase complex in only one case (case 5) did not dissociate after SDGU at pH 3.4 and 2.4 (Fig. 2c). These Ig-amylase complexes were not dissociated by treatment with $0.1 M$ 2-mercaptoethanol.

Addition of increasing volumes of macroamylase

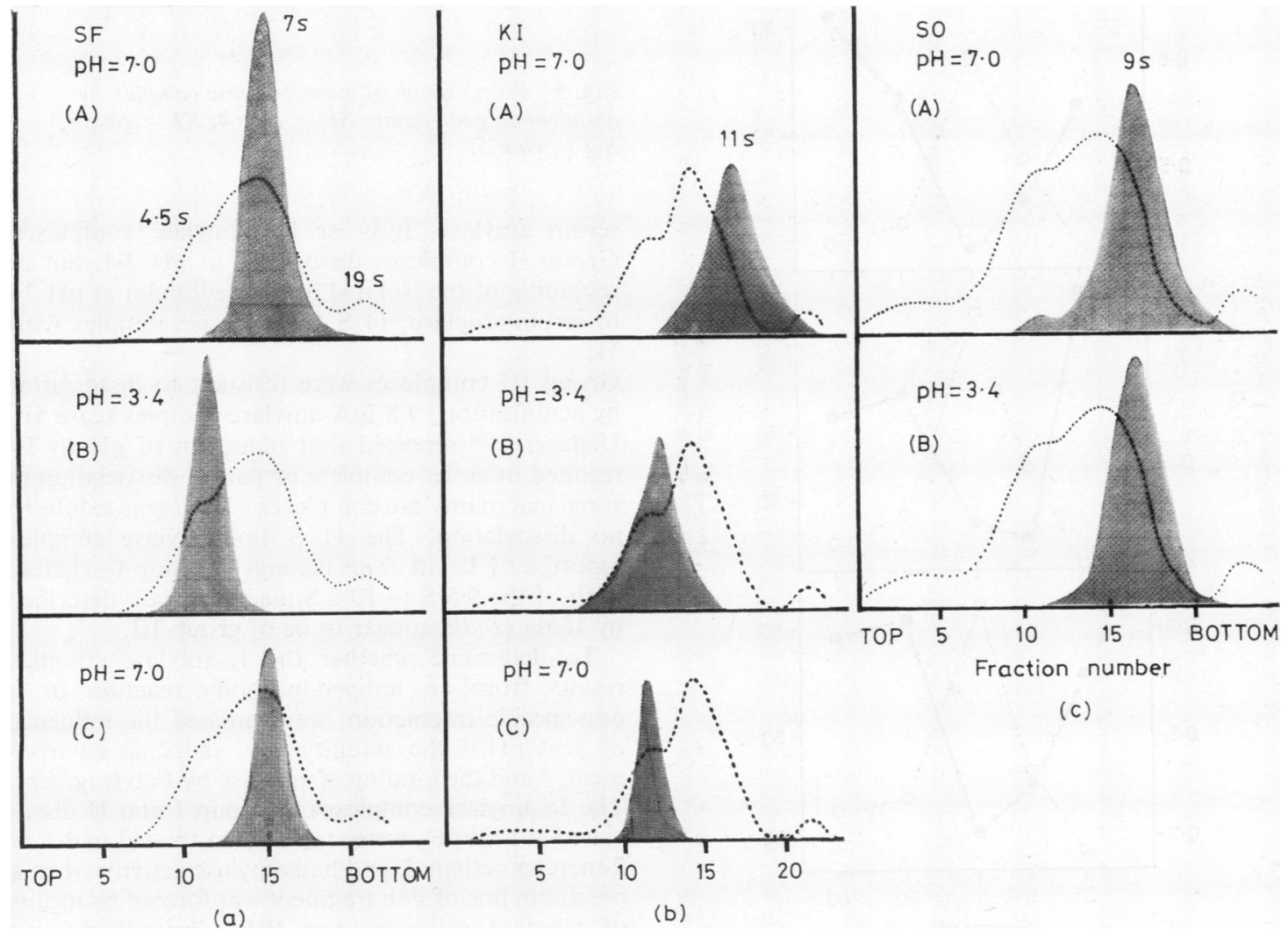

Fig. 2 Patterns before and after acidification, and patterns $(C)$ of dissociated immunoglobulin plus serum amylase by sucrose density gradient ultracentrifugation. $S F=$ case $4, K I=$ case $1, S O=$ case 5 . 
serum to antisera specific for IgA or IgG yielded precipitation of amylase. As the equivalence point for precipitation of the protein was reached, the amylase in the supernatant fluid decreased and then increased again as the equivalence point was passed (Fig. 3). Increasing quantities of the patient's serum were also added to the horse anti- $\alpha_{1} \mathrm{AT}$, or to the goat antial bumin antiserum. In only two cases (cases 5 and 1), which showed $9 \mathrm{~S}$ and $11 \mathrm{~S}$ Ig-amylase complexes, respectively, the amylase in the supernatant fluid was decreased by the addition of anti- $\alpha_{1} \mathrm{AT}$ and antialbumin antisera, that is, these Ig-amylase complexes were precipitated by both of the antisera (Figs. 4 and 5).

\section{Discussion}

We conclude from SDGU studies that the Igamylase complexes can be divided into three groups: Group I complexes dissociated at pH 3.4 and reformed at $\mathrm{pH} 7.0$ with the isolated Ig rebound to

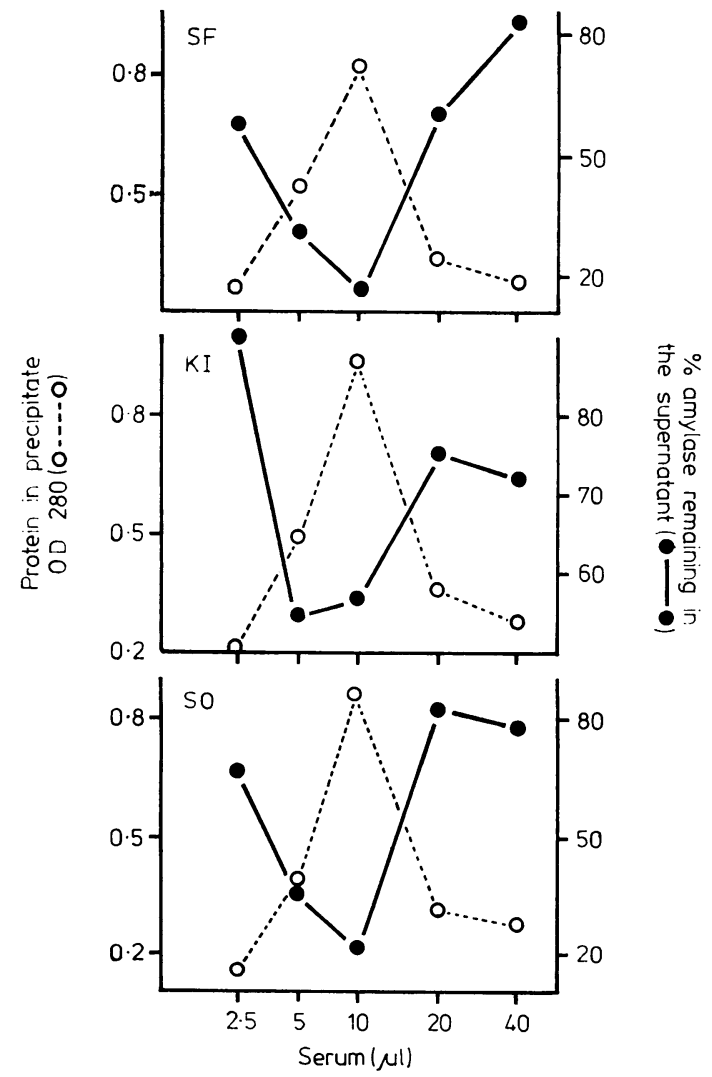

Fig. 3 Precipitation of macroamylase complex by anti-IgA goat serum $(S F=$ case 4$)$.

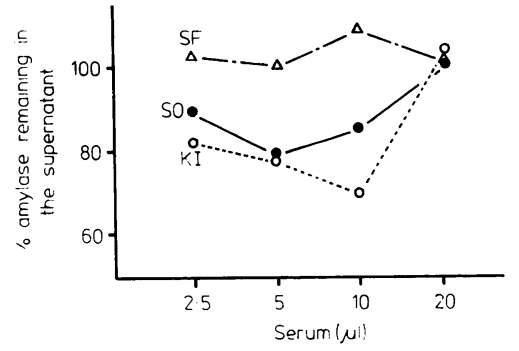

Fig. 4 Precipitation of macroamylase complex by anti- $a_{1} A T$ horse serum. $S F=$ case $4, K I=$ case $I$, $S O=$ case 5 .

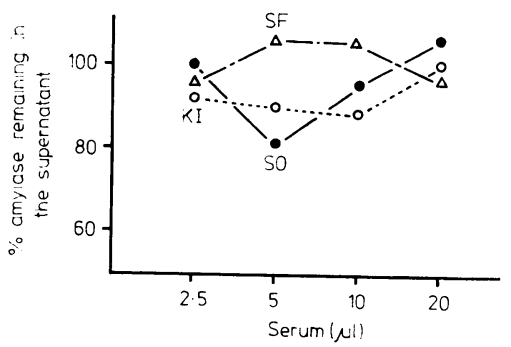

Fig. 5 Precipitation of macroamylase complex by antialbumin goat serum. $S F=$ case $4, K I=$ case $I$, SO $=$ case 5 .

serum amylase, IgA- or IgG-amylase complexes; Group II complexes dissociated at $\mathrm{pH} 3 \cdot 4$, but no rebinding of the isolated immunoglobulin at $\mathrm{pH} 7 \cdot 0$ to serum amylase; $11 \mathrm{~S}$ IgA-amylase complex (case $1)$;

Group III complexes were resistant to dissociation by acidification; $9 \mathrm{~S} \mathrm{IgA-amylase} \mathrm{complex} \mathrm{(case} \mathrm{5).}$ Ueda et al ${ }^{10}$ reported that reduction of $\mathrm{pH}$ to 3.4 resulted in either complete or partial dissociation of some macroamylase complexes while some exhibited no dissociation. The $11 \mathrm{~S}$ IgA-amylase complex reported by Levitt et al ${ }^{5}$ belongs to group I, whereas both of the $9.5 \mathrm{~S}$ to $10 \cdot 2 \mathrm{~S}$ macroamylase described by Ueda et al $^{10}$ appear to be of group III.

To determine whether the Ig-amylase complex results from an antigen-antibody reaction or a non-specific interaction, we examined the influence of acid $\mathrm{pH},{ }^{12}$ the stability in a reducing environment, ${ }^{13}$ and the binding of amylase by Fab fragment . The Ig-amylase complexes of group I and II dissociated at acid $\mathrm{pH}$, were stable when treated in $0.1 \mathrm{M}$ 2-mercaptoethanol, and had amylase activity when a precipitin line of Fab fragment was formed by means of amylase staining after IEP. Accordingly, we conclude that the binding characteristics of Igamylase complexes belonging to the group I and II 
are consistent with the behaviour of an antigenantibody reaction.

Five patients belonging to groups I and II were found to suffer from chronic pancreatitis or polyclonal hyperimmunoglobulinaemia, as shown in Table 1. In two of five patients between 45 to 76 years old autoantibodies including anti-DNA and RA factor were found. Accordingly, it was considered that the autoantibodies against amylase might be produced under these circumstances.

The Ig of group II may belong to IgA subclass 2 , which possibly dissociates at acid $\mathrm{pH} .{ }^{14}$ The binding mode of $9 \mathrm{~S} \mathrm{IgA-amylase} \mathrm{complexes} \mathrm{of} \mathrm{group} \mathrm{III,}$ which were unaffected by acidification, remains unknown.

Complex formation between IgA and several serum proteins has been noted previously. ${ }^{15} 16$ It has been demonstrated that the binding of albumin by IgA involves covalent disulphide bonds. ${ }^{1517}$ The IgA of both $9 \mathrm{~S}$ and $11 \mathrm{~S}$ IgA-amylase complexes might be non-specifically bound to other proteins including $\alpha_{1} \mathrm{AT}$ and albumin. Consequently it seems that the larger macroamylase complexes are formed.

\section{References}

${ }^{1}$ Wilding P, Cooke WT, Nicholson GI. Globulin-bound amylase. Ann Intern Med 1964;60:1053-9.

${ }^{2}$ Berk JE, Kizu H, Wilding P, Searcy RL. Macroamylasemia; newly recognized cause for elevated serum amylase activity. N Engl J Med 1967;277:941-6.

${ }^{3}$ Take S, Fridhandler L, Berk JE. Macroamylasemia; possible role of polysaccharide in composition of macroamylase. Clin Chim Acta 1970;27:369-71.

${ }^{4}$ Köhler H, Kirch W, Weihrauch TR, Prellwitz W, Horstmann HJ. Macroamylasemia after treatment with hydroxyethyl starch. Eur J Clin Invest 1977;7:205-11.
${ }^{5}$ Levitt MD, Cooperband SR. Hyperamylasemia from the binding of serum amylase by an $11 \mathrm{~S}$ IgA globulin. $N$ Engl J Med 1968;278:474-9.

${ }^{6}$ Hansen HR, Kley HV, Knight WA. Macroamylasemia due to binding by protein. Am J Med 1972;52:712-20.

${ }^{7}$ Kanno T. Studies on enzyme-linked immunoglobulins. Physicochemical Biology (Japan) 1977;21:1-5.

${ }^{8}$ Levitt MD, Goetzl EJ, Cooperband SR. Two forms of macroamylasemia. Lancet $1968 ;$; :957-8.

${ }^{9}$ Ueda M. Ultracentrifugal characteristics of macrohyperamylasemia serum. C!in Chim Acta 1971;35:299. 304.

10 Ueda M, Berk JE, Fridhandler L. Macroamylasemia; variation in the response of the macroamylase complex to acidification. Proc Soc Exp Biol Med 1971;137:1152-6.

11 Potter RR. Hydrolysis of rabbit globulins and antibodies with crystalline papain. Biochem J 1959;73:119-26.

${ }^{12}$ Singer SJ, Campbell DH. Physical chemical studies of soluble antigen-antibody complexes. IV. Effect of $\mathrm{pH}$ on reaction between bovine serum albumin and its rabbit antibodies. J Am Chem Soc 1955;77:3504-10.

${ }^{13}$ Ishizaka $\mathrm{K}$, Ishizaka $\mathrm{T}$, Lee $\mathrm{EH}$. Immunochemical properties of human $\gamma \mathrm{A}$ isoagglutinin. II. Effect of reduction and alkylation. J Immunol 1965;95:771-80.

14 Grey HM, Abel CA, Yount WJ, Kunkel WG. A subclass of human $\gamma \mathrm{A}$-globulins $(\gamma \mathrm{A} 2)$ which lacks the disulfide bonds linking heavy and light chains. $J$ Exp Med 1968; 128:1223-36.

${ }^{15}$ Tomasi TB, Hauptman SP. The binding of $a-1$ antitrypsin to human IgA. J Immunol 1974;112:2274-7.

${ }^{16}$ Ohtani H, Kawai T, Koide A. Studies on the bindings of IgA type M-proteins. Physicochemical Biology (Japan) 1974;19:445-6.

17 Mannik M. Binding of albumin to $\gamma \mathrm{A}$-myeloma proteins and Waldenström macroglobulins by disulfide bonds. J Immunol 1967;99:899-906.

Requests for reprints to: Dr H Ohtani, Department of Clinical Pathology, Kitasato University School of Medicine, Sagamihara-shi, Kitasato, 1-15-1, Kanagawa, Japan 228. 